\title{
DELINEAMENTO DE ATRIBUTOSE ESPECIFICAÇÕES TÉCNICAS DE EPI PARA OS PÉS NO PLANTIO DA MUDA DO ABACAXI
}

\section{DESIGN OF ATTRIBUTES AND TECHNICAL SPECIFICATIONS OF PPE FOR FEET WHEN PLANTING PINEAPPLE SEEDLINGS}

Frederico Reinaldo Corrêa de Queiroz ${ }^{7}$

Mauro José Andrade Tereso ${ }^{2}$

Roberto Funes Abrahão ${ }^{3}$ José Carlos Plácido da Silva ${ }^{4}$ 


\section{Resumo}

Segurança e a qualidade de vida encontram-se entre os maiores problemas da agricultura contemporânea. O uso de EPI ainda representa a principal estratégia para atenuar os riscos aos quais os trabalhadores agrícolas estão expostos. Entretanto, os EPI raramente são avaliados quanto a sua eficiência ergonômica ou aceitação de conforto por parte dos usuários. O objetivo desta pesquisa foi delinear atributos e especificações técnicas para conceber um conjunto de EPI que atendesse simultaneamente aos requisitos de segurança, conforto e usabilidade no plantio do abacaxi. A associação parcial dos métodos AET e QFD se mostrou bastante adequada para o desenvolvimento de artefatos de proteção.

Palavras-chave: Ergonomia; Design; Agricultura; Análise do Trabalho; Desdobramento da função qualidade.

\section{Abstract}

Safety and quality of life are among the biggest problems in contemporary agriculture. The use of PPE still represents the main strategy to mitigate the risks to which crop workers are exposed. However, PPE is rarely evaluated for its ergonomic efficiency or comfort acceptance by users. The objective of this research was to outline attributes and technical specifications to design a set of PPE that simultaneously met the requirements of safety, comfort and usability when planting pineapples. The partial association of the EWA and QFD methods proved to be quite adequate for the development of protective artifacts.

Key-words: Ergonomics; Design; Agriculture; Work Analysis; Quality function deployment.

1 frcqueiroz@gmail.com

2 mauro@unicamp.br

3 funes@unicamp.br

4 jcplacido@gmail.com 


\section{INTRODUÇÃO}

A agricultura é uma das poucas atividades onde se concentram quase todos os tipos de trabalho humano: trabalho primário, com a produção de alimentos; trabalho secundário, com o desenvolvimento de máquinas e ferramentas; e o trabalho terciário, com a gestão e comercialização (WISNER,1987).

Ferreira de Sousa e Santana (2016) destacam que o trabalho na agricultura é classificado como uma atividade de alto risco quanto a acidentes e adoecimentos laborais em um âmbito mundial. Fathallah (2010) aponta o alto índice de lesões de natureza variada e adoecimentos relacionados ao trabalho rural, que muitas vezes não são identificados em seus nexos causais. Os distúrbios osteomusculares devido à grande movimentação de carga com pesos elevados, movimentos repetitivos por longas jornadas de trabalho e exposição a produtos químicos tóxicos, caracterizam esse setor como sendo um dos mais perigosos.

O Brasil é um dos maiores produtores agrícolas do mundo e, segundo o Censo Agropecuário de 2016, possui cerca de 18 milhões de trabalhadores rurais, o que representa aproximadamente $14 \%$ de todos os trabalhadores em atividade. A Secretaria Especial de Previdência e Trabalho (SEPRT) do Ministério da Economia (ME) reconhece a agropecuária e suas ramificações como sendo um setor de "alto risco" quanto a segurança e saúde ocupacional, classificando-a no grau 3 em uma escala de 1 a 4.

De acordo com Ferreira de Sousa e Santana (2016), o Brasil teve quase 9000 óbitos de trabalhadores rurais na primeira década do século XXI. A taxa de mortalidade foi de 7,3 mortes a cada 100 mil trabalhadores rurais, valor $63 \%$ maior que os da União Europeia. Na perspectiva da segurança e saúde do trabalhador, o setor é considerado precário e carente de muitas melhorias.

lida (2005) adverte que as pesquisas e aplicações da ergonomia na agricultura são modestas e recentes, se comparadas com as intervenções na indústria. Ao contrário do que ocorre nas fábricas, os trabalhadores agrícolas raramente possuem função ou local fixo de trabalho, além de suas tarefas serem muito variáveis, já que a produção agrícola e pecuária varia com o desenvolvimento das culturas ou dos animais. As atividades geralmente são árduas, executadas em posturas desconfortáveis, com elevada exigência de força muscular, e que ocorre em ambientes desprotegidos. Os trabalhadores do setor agropecuário possuem pouco acesso a treinamentos e recebem baixas remunerações. Isso proporciona maiores chances de erros na atividade, incrementando as condições para acidentes e adoecimento.

Meirelles et. al. (2012) destacam que para lidar com estes fatores de riscos do setor agrícola através de uma visão sistêmica, as soluções deveriam seguir uma hierarquia de prioridades, como a prevenção inicialmente, seguida da proteção coletiva e por fim a opção pelos EPI. Entretanto, a última opção é a preferida pelos empregadores devido ao menor custo. Se o EPI não for adequado para as condições de trabalho, pode dificultar as atividades diárias e até mesmo potencializar os fatores de risco.

No entanto, a NR-01 - Disposições Gerais (Alterada pela Portaria SEPRT n. ${ }^{\circ} 6.730$, de 09/03/2020), aprovada pela Portaria 3.214 de 8/06/1978, sobre prevenção e/ou proteção de acidentes e doenças do trabalho, preconiza que é de responsabilidade do empregador elaborar ordens de serviço sobre segurança e saúde no trabalho, informando aos trabalhadores os fatores de riscos que se encontram no ambiente de trabalho, as 
formas para prevenir e limitar esses riscos, além das medidas que forem adotadas pela empresa como formas de prevenção e/ou proteção para possíveis acidentes ou doenças. Essas medidas possuem uma ordem de prioridade a ser seguida e devem contar com a participação dos trabalhadores em sua elaboração e implementação, conforme o subitem g) do item 1.4.1 que determina a seguinte ordem de prioridade:

I. Eliminação dos fatores de risco;

I. Minimização e controle dos fatores de risco, com a adoção de medidas de proteção coletiva;

I. Minimização e controle dos fatores de risco, com a adoção de medidas administrativas ou de organização do trabalho; e

I. Adoção de medidas de proteção individual.

Já a Norma Regulamentadora nº 09 (NR-09 - Programa de Prevenção de Riscos Ambientais - PPRA), aprovada pela Portaria 3.214 de 8/06/1978, em seu item 9.3.5.5 determinava que:

A utilização de EPI no âmbito do programa deverá considerar as Normas Legais e Administrativas em vigor e envolver no mínimo:

a) seleção do EPI adequado tecnicamente ao risco a que o trabalhador está exposto e à atividade exercida, considerando-se a eficiência necessária para o controle da exposição ao risco e o conforto oferecido segundo avaliação do trabalhador usuário; [grifo nosso] (...)

Deve-se salientar que, com a inclusão do Programa de Gerenciamento de Riscos (PGR) na NR 1, o PPRA descrito na NR 9 deixa de existir (alterada pela Portaria SEPRT n. ${ }^{\circ}$ 6.735, de 10 de março de 2020).

Veiga et. al. (2007) salientam que:

no Brasil, o problema de inadequação dos EPIs às condições ergonômicas e ambientais também não é estranho. Na agricultura brasileira, especialmente em pequenas comunidades rurais, é comum deparar-se com trabalhadores rurais sem os EPIs obrigatórios durante a manipulação e a aplicação de agrotóxicos. Uma das principais razões para não se utilizar EPIs reside no fato de que muitos dos EPIs utilizados na agricultura, devido a sua inadequação, podem provocar desconforto térmico, tornando-os bastante incômodos para uso, podendo levar, em casos extremos, ao estresse térmico do trabalhador rural.

Entre as atividades agrícolas, a produção de frutas merece uma atenção, pois o Brasil é atualmente o maior produtor no mundo. O país concentra suas exportações nas frutas cítricas, que atingiram uma receita aproximada de US \$1,1 bilhão no ano de 2016. Dentre essas frutas, o abacaxi se destaca entre as mais produzidas, sendo o Brasil o segundo maior produtor mundial (IAC, 2016).

A produção do abacaxi tem recebido pouca atenção dos pesquisadores no que tange às questões relativas à segurança, saúde e ergonomia nas condições de trabalho. Nesse contexto, destacam-se no Brasil três publicações contemporâneas voltadas à segurança do trabalho para esse setor de atividade.

Na primeira, Adissi \& Almeida (2002) buscaram identificar os fatores de riscos pre- 
sentes no cultivo do abacaxi. Utilizaram a técnica da análise coletiva do trabalho com os atores sociais envolvidos na produção do abacaxi na Paraíba. Foram identificados fatores de risco em todas as fases do processo produtivo do abacaxi, além de destacar várias adversidades de ordem social e econômica.

Já na segunda publicação, Gonzaga et al. (2014) realizaram uma investigação sistêmica das condições de trabalho no cultivo do abacaxi em Guaraçaí-SP, tento como demanda do estudo a avaliação dos EPI utilizados nessa cultura. Destacaram a inadequação dos EPI, tanto na proteção efetiva dos trabalhadores quanto como elemento que dificultou a realização das atividades. A pesquisa sistematizou os fatores de risco e expos a precariedade das condições físicas e sociais associadas ao trabalho na cultura do abacaxi.

A terceira publicação corresponde ao doutorado da autora Gonzaga (GONZAGA, 2017), que procurou avaliar a eficácia de um conjunto de EPI usualmente utilizado pelos trabalhadores no cultivo do abacaxi, em especifico na proteção contra o ataque de serpentes. Concluiu-se pela necessidade da concepção de EPI específicos para as diversas atividades no cultivo do abacaxi.

É evidente que o trabalhador agrícola precisa que se desenvolvam EPI adequados a cada uma de suas inúmeras atividades e que ofereçam condições mínimas de conforto.

Akbar-Khanzadeh et. al. (1995) apontam que conforto é um termo relativo, geralmente determinado por uma combinação de fatores fisiológicos, psicológicos e físicos. O ajuste inadequado, o peso adicionado, o estilo fora de moda ou a cor tornam muitos EPI indesejáveis. Alguns tipos de EPI resistem à passagem do vapor de água e inclusive impedem o movimento do ar em torno da pele, dificultando o resfriamento pela evaporação do suor. Os EPI também podem aumentar o gasto metabólico da execução de uma tarefa adicionando peso e limitando movimentos do trabalhador. Além disso, - EPI pode restringir campos visuais, limitar a comunicação e reduzir destreza manual.

Esses problemas também podem afetar o desempenho de um trabalhador e criar riscos maiores do que os perigos contra os quais o EPI foi projetado. A relutância dos trabalhadores em usar o EPI também pode ser atribuída ao fato dele se tornar um obstáculo ao trabalho e a percepção dos trabalhadores de que é desnecessário ou inadequado para sua proteção.

Garrigou et. al. (2008) afirmam que devemos considerar as questões da concepção e do uso dos EPI como uma problemática de transferência de tecnologias, pois foram concebidos para situações de utilização que correspondem muito pouco à real condição de trabalho dos agricultores. Ressalvam que é importante considerar que os EPI não podem ser abordados exclusivamente de um ponto de vista técnico. Esta questão implica dimensões subjetivas e sociais profundamente interligadas, apesar dos EPI serem vistos como um símbolo da prevenção.

$\mathrm{Na}$ concepção de artefatos inovadores, Zhang et. al. (2014) esclarecem que a estética do design adequado do produto e a satisfação do usuário são requisitos fundamentais no momento do desenvolvimento do projeto. 
Baxter (2000) reflete que a criatividade é a essência do design em todos as etapas de um projeto, e por esse motivo:

Há muita verdade na afirmação de Thomas Edison: "criatividade é 1\% de inspiração de 99\% de transpiração". A criatividade geralmente resulta de associações, combinações, expansões ou visão, sob um novo ângulo, de ideias existentes. A preparação é o processo pelo qual a mente fica mergulhada nessas ideias existentes. Mesmo quando não se trabalha no nível consciente, a mente continua a processar essas ideias. Então, quando menos se espera, a solução pode surgir repentinamente. Mas isso só acontece quando houver a preparação, colocando-se na mente todos os elementos essenciais para a solução do problema. Uma grande ideia criativa não surge no vácuo, mas quando houve um esforço consciente na busca da solução. (...)

Tanto para Löbach (2001) como Pazmino (2015), todo o processo de design é de certa forma um processo criativo e um processo de solução de problemas para atender os desejos e necessidades dos usuários e/ou processos de manufatura, através de produtos ou serviços adequados que atendam os fatores tecnológicos, ergonômicos e funcionais entre outros. A compreensão da interface humano-produto é complexa até mesmo no caso dos produtos mais simples. Uma análise mais detalhada é que acaba sendo fonte de informações para o projeto de novos produtos, pois se acaba descobrindo uma nova forma de utilização, um novo desejo ou necessidade e até desconfortos que podem ser solucionados. Esse método é conhecido como análise da atividade, no qual envolve observar, descrever e detectar pontos negativos e positivos existentes em relação ao uso do produto ou serviço. Ainda como suporte para auxiliar a análise da atividade utiliza-se de ferramentas como fotos, filmagens, listas de verificação ou ckecklist, questionários ou entrevistas que apontem para questões genéricas de avaliação ergonômica, bem como indicando os aspectos de desconforto e as possíveis soluções para melhorar a usabilidade de cada produto ou serviço.

Segundo Guérin et al. (2001), a análise da atividade contesta os métodos habitualmente utilizados para conceber os meios de produção, que muitas vezes subestimam as oscilações do trabalho, os constrangimentos ligados às condições laborais e as singularidades dos trabalhadores. Ela permite levar em conta os atributos desses trabalhadores na concepção das técnicas e dos modos de organização do trabalho, além de orientar as escolhas nesses domínios para a busca de meios que aumentem as "margens de manobra" dos trabalhadores, de forma que, frente às inconstâncias em sua atividade, possam empregar estratégias que sejam coerentes com sua diversidade e sua própria variabilidade.

Wisner (2004) afirma que a característica essencial da Análise Ergonômica do Trabalho (AET) é de ser um método destinado a examinar a complexidade da tarefa, sendo utilizada para responder a uma questão precisa da demanda e é orientada para a proposição de soluções operatórias. Esta abordagem é oposta à das ciências aplicadas, que ensaia em campo os modelos elaborados em laboratório graças ao método experimental (abordagem top down ou descendente). A AET faz parte das abordagens ascendentes (ou bottom up) e se aproxima, por causa disto, de outros métodos análogos das Ciências Humanas: etnologia e psicodinâmica.

Para Béguin (2008), a ergonomia busca compreender as relações entre a concepção dos produtos ou sistemas de trabalho e as atividades profissionais, considerando a inteligência dos trabalhadores e evidenciando a inventividade através da ergono- 
mia da atividade. A atividade é fonte de criatividade situada, que explora, interpreta e reorganiza os dados e as decisões ao longo de seu desenvolvimento. Béguin (2016) reforça que não podemos nos limitar à concepção dos artefatos, pois a concepção é um processo de desenvolvimento conjunto dos artefatos e das atividades de quem vai usá-los.

A atividade é mediatizada tanto por artefatos como por instrumentos. Os artefatos abrangem equipamentos, máquinas, sinais e a própria linguagem, que são criados pelos operadores para controlar seu próprio comportamento no trabalho. Por sua vez, o instrumento é uma unidade mista, que compreende um artefato material ou simbólico (ou uma fração sua), e um ou vários esquemas de utilização, fazendo do instrumento um componente funcional da ação do operador. O processo em que o operador elabora, constrói, institui e transforma os instrumentos, constitui a chamada "gênese instrumental" (DARSES et al., 2007).

Elucida Béguin (2008) que as "gêneses instrumentais" são uma fonte de inventividade dos operadores, possibilitando ações sobre a concepção. A incorporação de um item técnico auxilia na solução de disfunções em equipamentos ou no local de trabalho.

Para Bourmaud (2016), "dois processos participam nessa gênese instrumental, e cada um é caracterizado pela sua orientação: trata-se dos processos de instrumentalização e instrumentação, que contribuirão para o desenvolvimento tanto do artefato como do operador". Sendo que a instrumentalização altera a concepção do artefato, constituindo um enriquecimento das propriedades do artefato pelo operador. Isso sucede, quando por exemplo os trabalhadores rurais do corte de cana emborracham os cabos de madeira dos facões, enrolando tiras de câmaras de pneus para garantir a aderência em suas mãos, alteram consideravelmente a concepção original do artefato. Já o processo de instrumentação afeta as estratégias e forma de utilização do artefato. A instrumentação está voltada diretamente para o operador, sendo um processo de desenvolvimento dos instrumentos ou artefatos, que ocorre em seu nível cognitivo e é resultante de uma elaboração de estratégia própria. Tem-se como exemplo o ato de utilizar uma chave inglesa como martelo, onde fica evidenciado que houve modificação na forma de utilização para o qual o artefato fora concebido originalmente.

Madureira (2010) afirma que:

a incorporação ao produto das necessidades, expectativas e exigências do cliente é essencial para o sucesso. Um método geral, bastante eficiente, o Quality Function Deployment (QFD - ou, em português, Desdobramento da Função Qualidade), que foi desenvolvido a partir de 1970, pela indústria japonesa, no contexto da chamada Qualidade Total. Embora conceitualmente muito antigo, o QFD, como outras técnicas modernas, resultou da combinação ordenada de atividades conhecidas, antes exercidas de forma mais ou menos dispersa, nos vários níveis das empresas industriais. (...)

Segundo Cheng \& Melo Filho (2010), a Matriz da Qualidade é geralmente a primeira matriz a ser construída em um projeto que utiliza QFD e pode ser definida como:

Matriz da Qualidade é a matriz que tem por finalidade executar o projeto da qualidade, sistematizando as verdadeiras qualidades exigidas pelos clientes por meio de expressões linguísticas, mostrando a correlação entre essas expressões e as características da qualidade do produto, e convertendo a importância atribuída aos itens de qualidade exigida, obtida 
no planejamento da qualidade, para os itens de características da qualidade que devem ser projetados.

Para Rozenfeld (2010), a essa matriz foram agregadas várias tabelas que auxiliam a calcular o grau de importância de um requisito do cliente (qualidade exigida) a partir: (a) da análise da natureza do requisito segundo o grau de percepção do cliente (requisito óbvio, linear e atrativo); (b) de uma avaliação comparativa com os principais concorrentes (benchmarking) e (c) de um fator que mede o impacto deste requisito na venda (argumento de venda).

Pazmino (2015) salienta que a ferramenta QFD é complexa para ser montada, sendo um dos motivos de seu pouco uso no meio acadêmico e empresarial. Contudo, é um método muito interessante que inventores, projetistas e designers devem conhecer para que as necessidades ou desejos dos consumidores sejam traduzidos de forma eficiente em especificações técnicas relevantes para os produtos ou serviços.

Para abordar o complexo tema do projeto de EPIs para o trabalho agrícola, este trabalho propõe a associação de dois métodos: da Ergonomia, a análise da atividade, a partir da observação do trabalho real; do design, o método do desdobramento da função qualidade (QFD). Em particular, foi objetivo deste trabalho delinear atributos e especificações técnicas para a concepção de um conjunto de EPI para a proteção dos pés, que fossem eficientes no controle dos fatores de risco presentes na atividade de plantio na cultura do abacaxi; que ao mesmo tempo não limitassem a execução das atividades e minimizassem ao máximo o desconforto.

\section{Métodos}

\subsection{Análise do Trabalho}

O método da Análise Ergonômica do Trabalho (AET) foi utilizado parcialmente na análise do trabalho envolvido no plantio das mudas do abacaxi. A AET se apresenta em três macroetapas - a análise da demanda, da tarefa e da atividade - e envolve observações gerais e sistemáticas do trabalho real e interações verbais com os atores do trabalho. Procurou-se, através das observações e pela aplicação de entrevistas semiestruturadas, fotos e filmagens, compreender o uso efetivo feito pelos trabalhadores dos EPI disponíveis, incluindo avaliações qualitativas da eficácia e da conveniência dos mesmos. Foi também aplicado um questionário contendo 29 questões baseado na metodologia de Likert modificado. Os temas tratados envolviam as condições de trabalho observadas no experimento; o uso dos EPI; proteção dos pés; opiniões e sugestões. As questões também procuravam avaliar os EPI segundo critérios de uso, mais especificamente relacionados ao esforço (sensação de peso e forças necessárias na manipulação); conforto (físico, térmico, postural e relativo ao contato com o equipamento) e usabilidade (facilidade, rapidez, adequações, dificuldades, limitações, estética e satisfação com o uso).

Participaram da análise dez trabalhadores que plantaram mudas de abacaxi em cultivos de Aparecida de Minas, um subdistrito da cidade de Frutal, estado de Minas Gerais. O estudo foi aprovado pelo Comitê de Ética em Pesquisa da Faculdade de Ciências Médicas da Universidade Estadual de Campinas.

Também foi aplicada a vinte e seis trabalhadores na propriedade pesquisada a 
escala de Borg, sobre percepção do esforço no trabalho, para que se pudesse avaliar a tarefa de plantio das mudas do abacaxi. Todos esses trabalhadores tinham experiência no cultivo do abacaxi em todas as suas fases. Dez deles participaram das avaliações de campo sobre a tarefa de plantio de abacaxi. A figura 01 foi apresentada a estes 26 trabalhadores que indicavam a sua percepção sobre a tarefa plantio de mudas baseados em suas experiências anteriores.

Figura 01 - Escala de Borg utilizadas na percepção da tarefa plantio de mudas

\begin{tabular}{|l|l|l|l|l|l|l|}
\hline 1 & 2 & 3 & 4 & 5 & 6 & 7 \\
\hline $\begin{array}{l}\text { Extremamente } \\
\text { Leve }\end{array}$ & Muito Leve & Leve & Pouco Intenso & Intenso & Muito Intenso & $\begin{array}{l}\text { Extremamente In- } \\
\text { tenso }\end{array}$ \\
\hline
\end{tabular}

\subsection{Aplicação do método QFD e construção da matriz de qualidade}

Por meio de uma matriz de qualidade ou primeira "casa da qualidade", o método QFD permitiu o "desdobramento" dos requisitos expostos pelos usuários/trabalhadores transformando-os em especificações técnicas do produto. Essa matriz foi construída a partir de uma tabela de desdobramento das qualidades exigidas (necessidades e/ou desejos) e as características técnicas da qualidade do produto necessárias ao desenvolvimento de EPI para os pés na operação de plantio das mudas do abacaxi.

O objetivo do desdobramento foi o de permitir que o desconhecido se tornasse conhecido, o que é implícito seja explicito, ou o que é informal seja formalizado. Para confeccionar as tabelas, recebe-se primeiramente a contribuição dos membros do grupo de desenvolvimento, por isso a necessidade de compreender a atividade e a organização do trabalho através da AET.

As Matrizes da Qualidade foram construídas conforme orientação e tutorial de Cheng \& Melo Filho no seu sentido restrito ao conteúdo desdobramento da qualidade (QD), onde esta versão do QFD fora desenvolvida por Makabe e transmitida por Don Clausing. Ficou explícito que essa pesquisa se ateve somente ao desdobramento da qualidade (QD), devido ao foco estar na aplicação operacional no desenvolvimento do produto para proteção dos trabalhadores no cultivo do abacaxi.

Com o desenvolvimento da tabela de desdobramento e da matriz de qualidade foi possível delinear os atributos e especificações técnicas de um produto (EPI) destinado à proteção dos pés dos trabalhadores durante o plantio de mudas do abacaxi.

\subsection{Para o desenvolvimento do EPI para os pés no plantio da muda do abacaxi}

Foi criada uma tabela de hierarquia de prioridades quanto ao peso relativo (PR) das qualidades exigidas e das características técnicas da qualidade do produto para proteção dos pés dos trabalhadores na atividade do plantio de mudas do abacaxi.

Em função da tabela hierarquia de prioridades quanto aos pesos relativos foram desenvolvidos produtos de proteção ergonômicos dos pés de forma a atender a atividade de plantio no cultivo do abacaxi pesquisado na região de Frutal, que futuramente poderão ser considerados EPI desde que atendam as normas e legislações vigentes 
para o mesmo.

Para auxiliar a criatividade utilizou-se ferramenta de busca na internet para artefatos e produtos semelhantes a necessidade do design sugerido pela tabela de hierarquia de prioridades, sendo considerado um "Brainstorm Digital no Google Imagens". Já os artefatos encontrados na forma física foram digitalizados com o auxílio do Scanner a laser 3D VIUscan de mão. Também se utilizou de offset do boneco SAE (percentil 50) para auxiliar no desenvolvimento dos protótipos digitais.

Desse modo através do conceito da "Gêneses Instrumentais", sugeriu-se a concepção de um protótipo digital através da associação de produtos com potenciais características de proteção já existentes no mercado e utilizados para outras finalidades em diversos setores.

A equipe de projeto também pôde incluir modificações na concepção e/ou quanto ao uso dos artefatos ergonômicos de proteção para os pés, tendo como alusão a expertise dos profissionais participantes, para assim mitigar a probabilidade de insatisfação quanto ao uso pelos trabalhadores no plantio do cultivo do abacaxi.

\section{Resultados e Discussão}

\subsection{Análise Ergonômica do Trabalho (AET) no Plantio da Muda do Abacaxi}

Na tarefa do plantio de muda do abacaxi a principal tarefa designada é a de que os trabalhadores desloquem as mudas do abacaxi dos locais depositados ao longo dos talhões até os canteiros de sua responsabilidade, com o auxílio de uma carriola adaptada com uma gaiola que permite transportar maior volume do carreto, para depois fazer o plantio nas covas demarcadas pelo trator. Também é de responsabilidade do plantador selecionar as mudas sadias (sem furos, manchas brancas, pragas ou quaisquer anomalias) e com tamanho uniforme (aproximadamente $30 \mathrm{~cm}$ ) antes de serem plantadas. As práticas observadas durante o plantio da muda do abacaxi compreenderam basicamente três operações: deslocamento das mudas dos locais depositados até os canteiros de sua responsabilidade; seleção das mudas do abacaxi sadias com tamanho uniforme; e plantio das mudas nas covas demarcadas pelo trator.

Os dez trabalhadores entrevistados possuíam idades entre 23 e 38 anos, todos do sexo masculino. A senioridade na função variou de 1 semana a 18 anos. Seis deles possuíam o ensino fundamental incompleto, três o ensino fundamental completo e um o ensino médio completo. Todos são terceirizados, trabalharam por sistema de remuneração por produção, sem carteira de trabalho assinada. Sete deles possuíam em uma segunda atividade não relacionada ao cultivo do abacaxi, necessária para complementar sua renda.

Um grupo de trabalhadores é organizado por um encarregado para prestar serviço na tarefa de carregamento de mudas e plantio na fazenda contratante no subdistrito de Aparecida de Minas. Eles recebem $\mathrm{R} \$ 23,00$ por milheiro de mudas, somados ao decorrer da semana pelo encarregado e com o acerto realizado aos sábados. Esse encarregado faz o transporte dos trabalhadores com uma Kombi (às vezes com outro veículo de passeio), embarcando os trabalhadores próximos de suas casas por volta das 6:00 horas. Após um deslocamento de cerca de $25 \mathrm{Km}$ por rodovia e mais $5 \mathrm{~km}$ por estrada de servidão chegam ao local estipulado para o plantio. Chegam ao local 
de trabalho antes das 7:00 horas. A prestação de serviço dura até o término do plantio na área estipulada pela fazenda contratante. Foram plantadas 33.000 mudas/hectare. Cada trabalhador plantou entre 3.000 a 8.000 mudas/dia. Caso haja chuva, o serviço pode ser interrompido.

Cada trabalhador traz sua refeição e água fresca em cantis térmicos. Não existem regras para as pausas. O trabalhador pode interromper o trabalho a qualquer momento. Ao término da jornada é realizada a conferência da produção de cada trabalhador.

A qualidade das mudas do abacaxi é previamente determinada pelo contratante, mas de responsabilidade dos trabalhadores. Erros podem gerar reclamações do contratante ao encarregado, pois o plantio deve gerar canteiros uniformes que facilitarão os tratos culturais nos próximos 18 a 20 meses do cultivo do abacaxi. Não existe uma produção estipulada individualmente ou por dia, mas sim uma área pré-determinada onde deve ser feito o plantio das mudas na fazenda. A qualidade do plantio é supervisionada pelo encarregado, que refaz pessoalmente os trechos que identifica como sendo fora do padrão exigido como pode ser observado na figura 02.

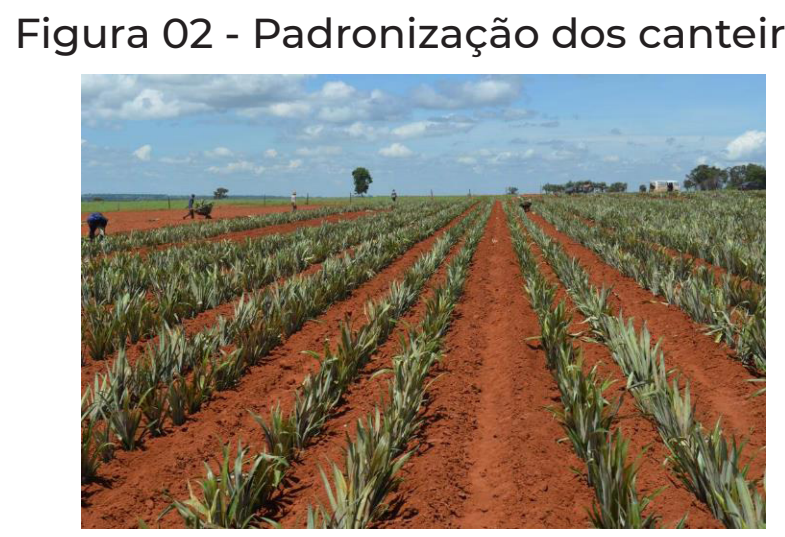

Fonte: autor

O ambiente laboral no plantio da muda do abacaxi possui condições e fatores de risco que, quando associados, tornam a atividade extremamente intensa e de risco. O trabalhador do plantio da muda do abacaxi convive no seu ambiente de trabalho simultaneamente com outras tarefas do cultivo do abacaxi em áreas contíguas, além de estar submetido às irregularidades do terreno e aos maquinários que circulam no ambiente de trabalho.

O trabalhar pode torcer o pé no solo fofo ou em buracos demarcados para o plantio. Há contato com animais silvestres que podem trazer doenças ou gerar acidentes. As grandes áreas a serem percorridas debaixo do sol para executar sua atividade no decorrer da jornada podem gerar exaustão, como pode ser observado na figura 03. 


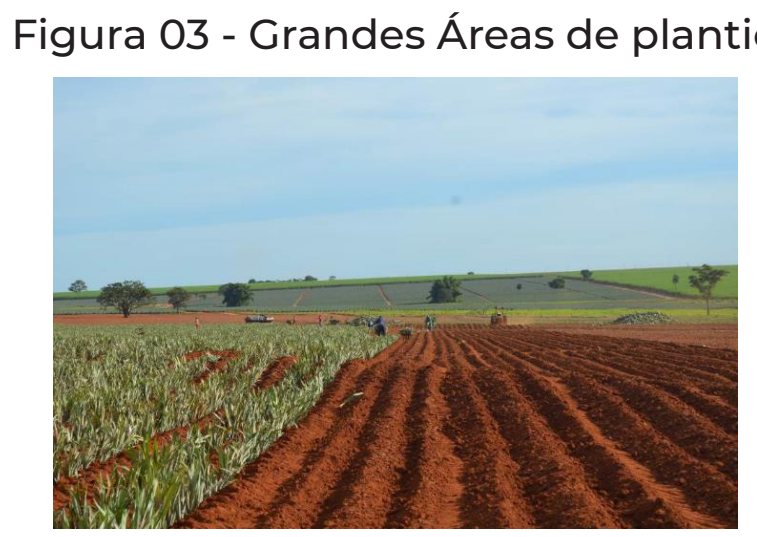

Fonte: autor

O trabalhador também exerce grande esforço físico e movimentos repetitivos para carregar a carriola com as mudas do abacaxi, como pode ser identificado na figura 04.

Figura 04 - Esforços e movimentos repetitivos

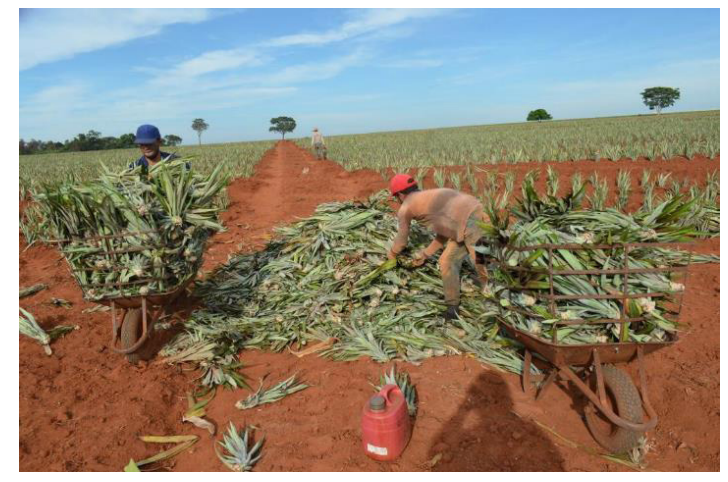

Fonte: autor

A tarefa de carregamento das mudas executados por vários trabalhadores ao mesmo tempo desprende muita poeira vegetal das mudas, por terem sido preparadas há dias e já se encontrarem desidratadas, como pode ser identificado na figura 05.

Figura 05 - Presença de poeira vegetal

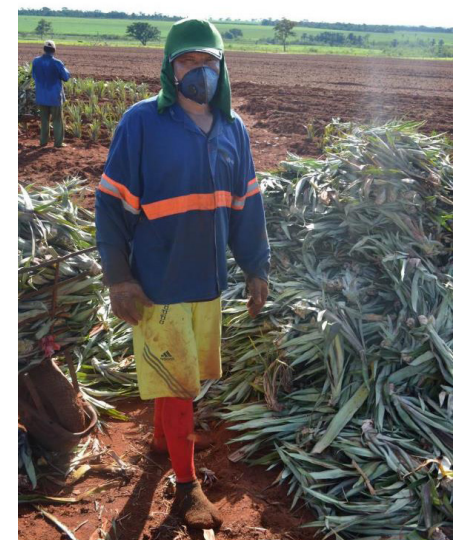

Fonte: autor 
O terreno irregular e íngreme exige grande esforço físico do trabalhador. As distâncias percorridas são grandes e contribuem para o desgaste físico do trabalhador. As condições do solo se constituem de verdadeiras armadilhas, com risco de quedas e torção dos pés, como pode ser identificado na figura 06.

Figura 06 - Terreno irregular e íngreme

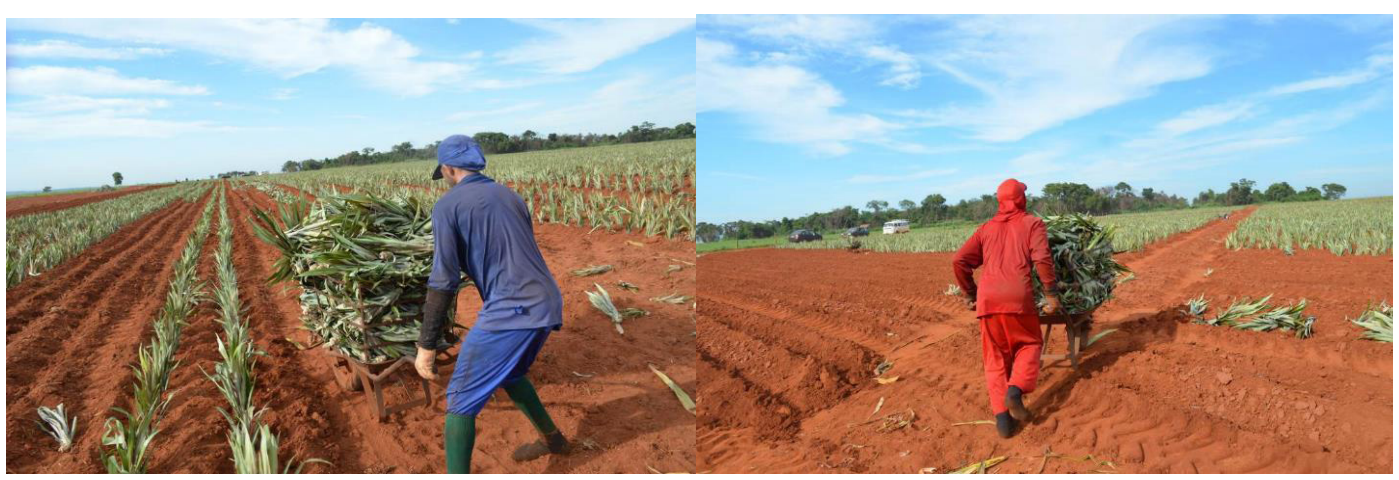

Fonte: autor

Posturas pouco adequadas e movimentos repetitivos aumentam risco de fadiga muscular e de problemas osteomusculares, como pode ser identificado na figura 07.

Figura 07 - Posturas inadequadas e movimentos repetitivos
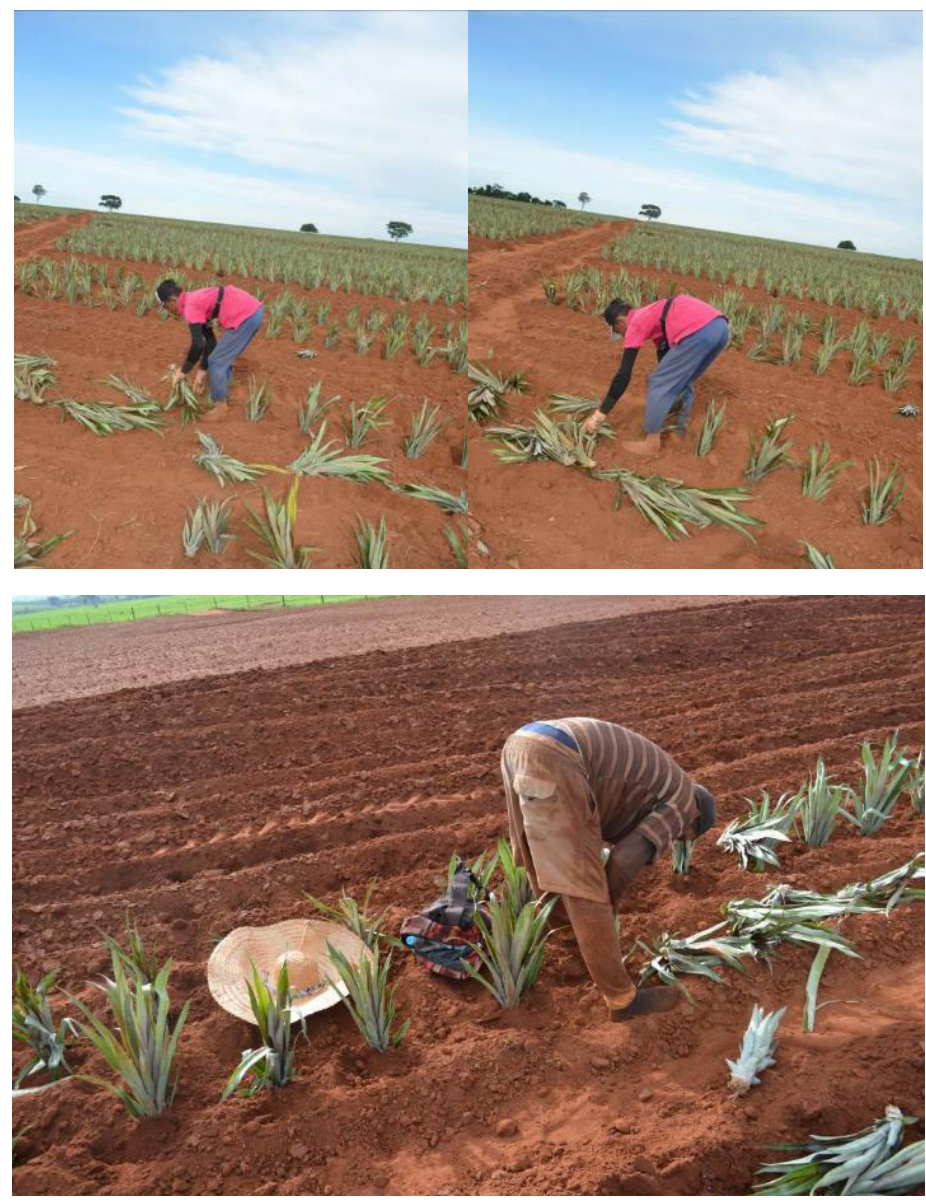

Fonte: autor 
Após a muda ser enterrada $10 \mathrm{~cm}$ no solo, o trabalhador faz o fechamento e a compactação ao seu redor com os pés. Por esta razão é comum trabalharem descalços ou com meias, como visualizado na figura 08.

Figura 08 - Trabalhador com meias posicionando e firmando a muda com os pés

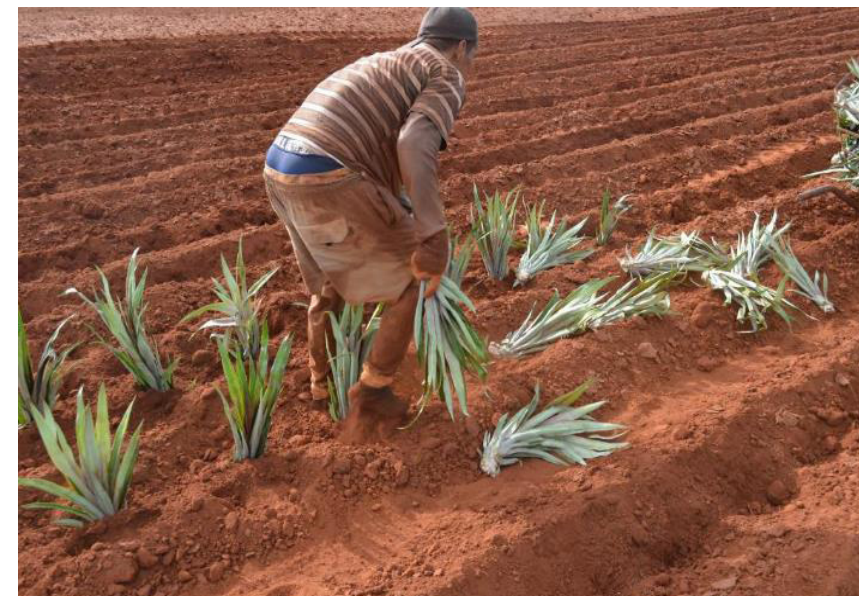

Fonte: autor

A presença de máquinas na preparação do solo em áreas contíguas ao plantio, expõe o trabalhador a um ambiente saturado por poeira mineral, como pode ser identificado na figura 09.

Figura 09 - Poeira mineral no ambiente laboral

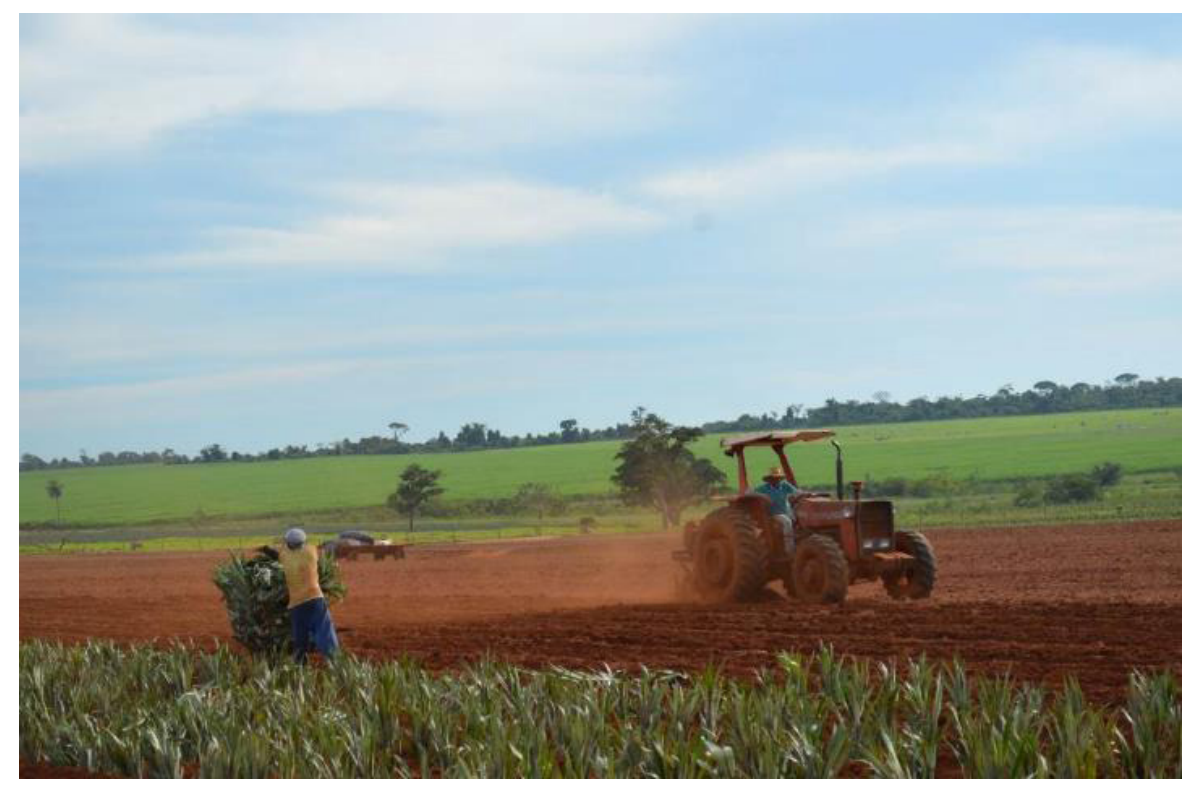

Fonte: autor

O plantio geralmente é feito nos momentos que antecedem as chuvas, colocando o trabalhador exposto a condições de baixa umidade e alta temperatura, além do desconforto térmico causado pelo contato do pé com o solo quente. 
Aplicada a 26 trabalhadores, a Escala de Borg, sobre percepção do esforço no trabalho, resultou que 23 deles apontaram esta tarefa como intensa a extremamente intensa.

\subsection{Condições de trabalho quanto ao uso dos EPI}

A porcentagem de trabalhadores rurais no plantio das mudas do abacaxi que avaliaram a atividade de forma negativa quanto ao uso de EPI foi superior a $90 \%$. Eles não receberam EPI dos contratantes no plantio de mudas (apesar da obrigatoriedade pela legislação), adquirindo-o por conta própria. Muitos já improvisaram alguma forma de proteção ou artefato semelhante ao EPI como também a sua substituição.

Os depoimentos dos trabalhadores a esse respeito foram os seguintes: "...Trouxe uniforme e alguns EPI da firma onde colhia laranja. Quando preciso de mais algum, compro em uma loja em Frutal..." (TR 13); "...Somente a luva comprei; o chapéu, a máscara e a camisa de proteção ganhei da minha prima que trabalha na usina..." (TR 15); “... Já fiz mangote com meia de futebol, sapatilha com meia de cotton e calça legging por baixo da bermuda..." (TR 11); "...Já fiz mangote com meião de futebol e costurei gorro na camisa para não cair quando me abaixo..." (TR 18) ; “...Eu mesmo substituo os EPI quando necessário..." (TR 12).

Na figura 10 observa-se exemplos de EPI ou adaptações voltadas para proteção da cabeça (chapéu ou boné árabe) e pernas (calça longa ou bermuda sobre calça legging). Na figura 11 observa-se adaptações para proteção dos braços (camisas de manga comprida ou meiões adaptados), mãos (luvas) e a utilização de meias para execução da tarefa de plantio.

Figura 10 - Proteções para cabeças e pernas

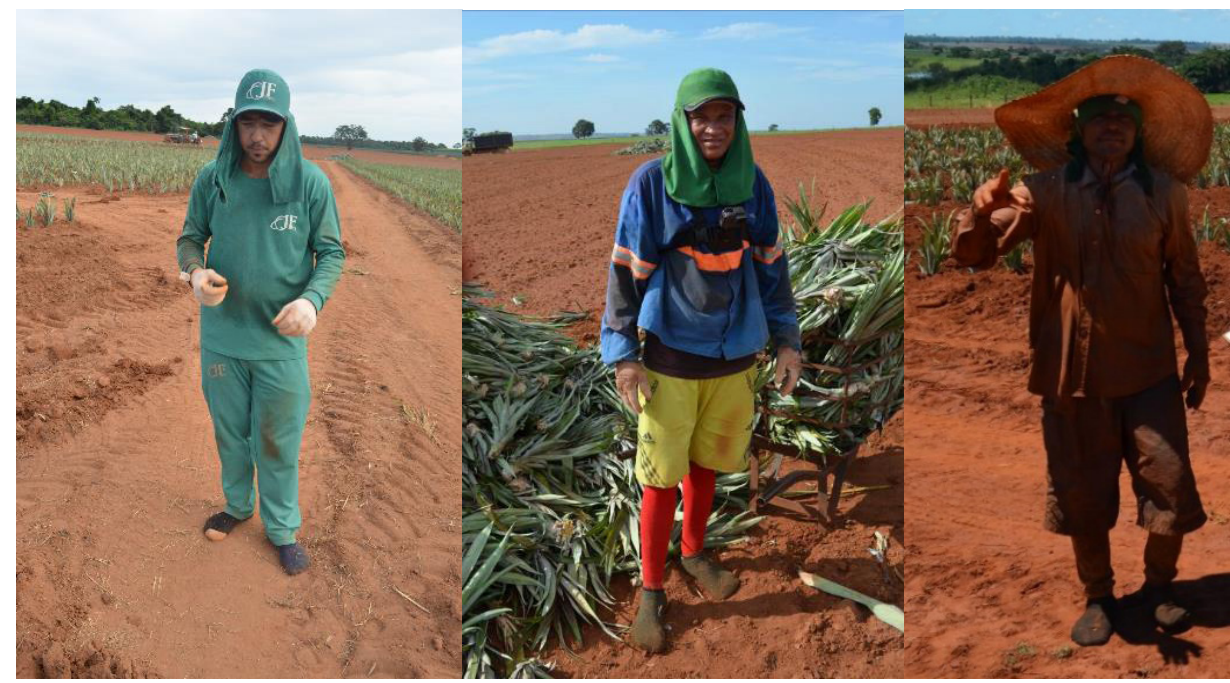

Fonte: autor 
Figura 11 - Proteções para os braços e utilização de meias

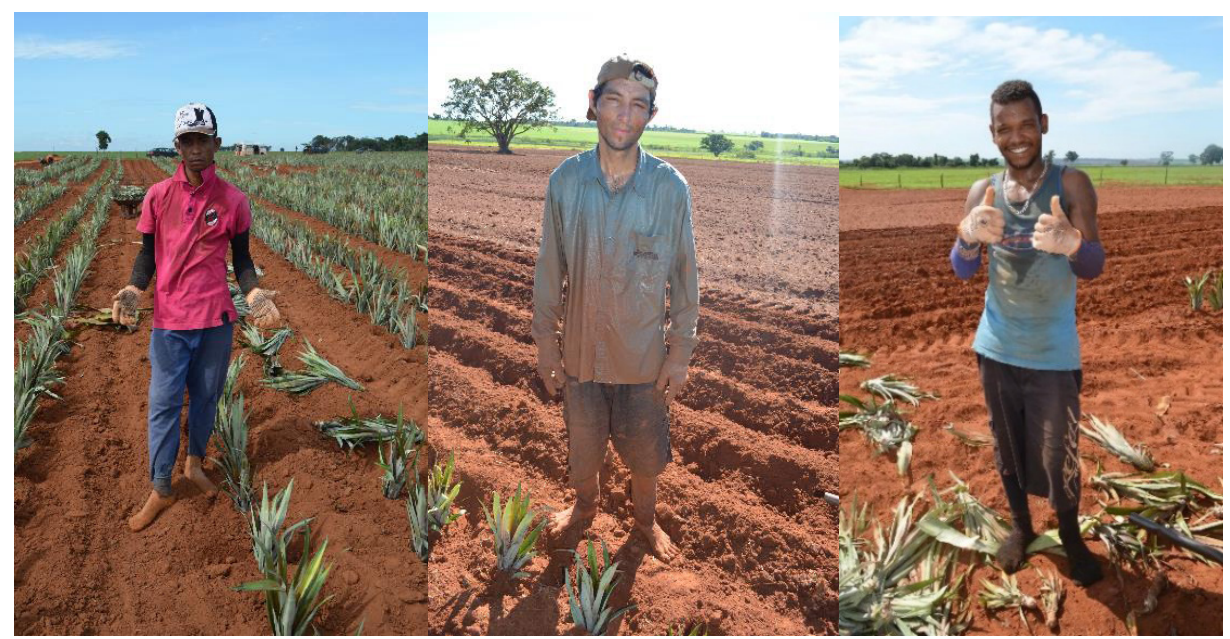

Fonte: autor

Dos 10 trabalhadores rurais entrevistados no plantio das mudas do abacaxi, 1 trabalhador utiliza proteção convencional (botina ou bota de segurança) e 09 trabalhadores utilizam alguma outra forma de defesa aos fatores de risco para os pés.

Todos os trabalhadores avaliaram negativamente a proteção dos pés de forma convencional tanto para aquecimento como para a transpiração. Estes são dados que merecem atenção e reflexão na concepção do EPI para proteção dos pés no plantio das mudas do abacaxi.

Um depoimento de trabalhador a respeito da transpiração dos pés foi o seguinte: “...Às vezes os pés transpiram muito dentro da botina, devido ao sol estar intenso..." (TR 18).

Já os depoimentos dos trabalhadores a respeito da proteção não convencional para os pés foram os seguintes: "...Uso meião de futebol com calça legging por baixo..." (TR 11); "...Utilizo meias grossas para proteger os pés contra o solo quente..." (TR 12) conforme figura 12; “...Uso dois meiões de futebol e uma meia fina por cima, porque a terra é muito quente e por causa das perfurações das mudas do abacaxi. Em dia de chuva fico descalço devido ao peso das meias úmidas e cheias de lama..." (TR 14); "...Mas como hoje choveu, eu estou descalço devido ao meião de futebol ficar pesado, cheio de lama e ainda sair do pé..." (TR 16) conforme figura 13.

Figura 12: Meiões de futebol por cima ou por baixo de calças
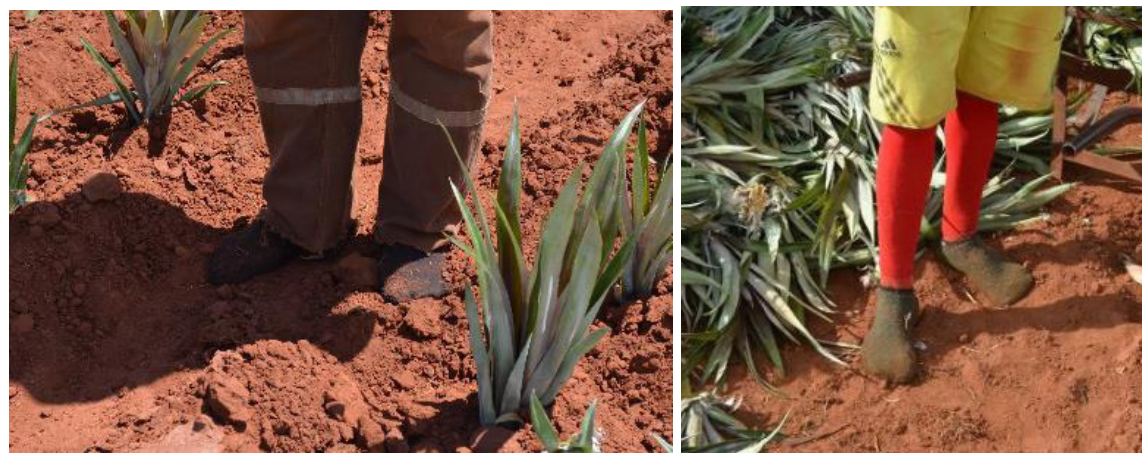

Fonte: autor 
Figura 13: Trabalhador descalço devido ao solo estar úmido

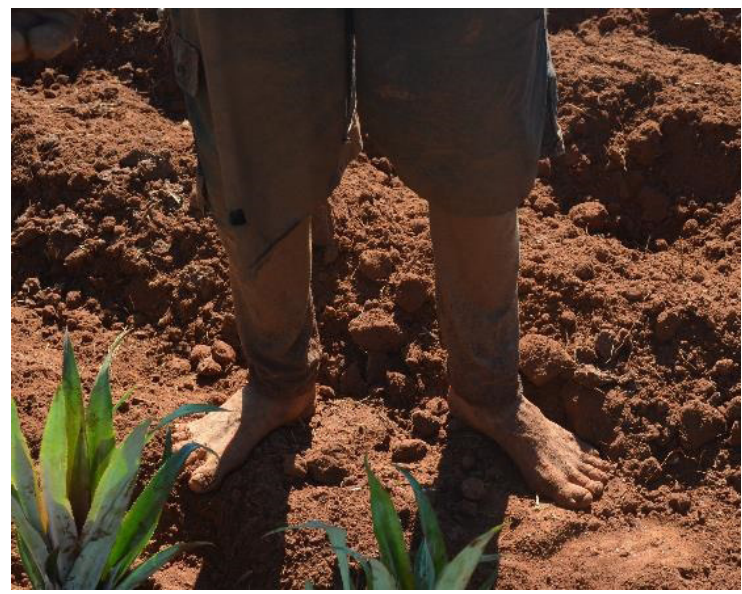

Fonte: autor

Existem trabalhadores rurais que começam trabalhando com meias e conforme aumenta a temperatura do solo optam por utilizar sapatilhas do gênero feminino, devido ser mais leves e confortáveis que os calçados comuns conforme figura 14.

Figura 14: Meias e sapatilhas feminina
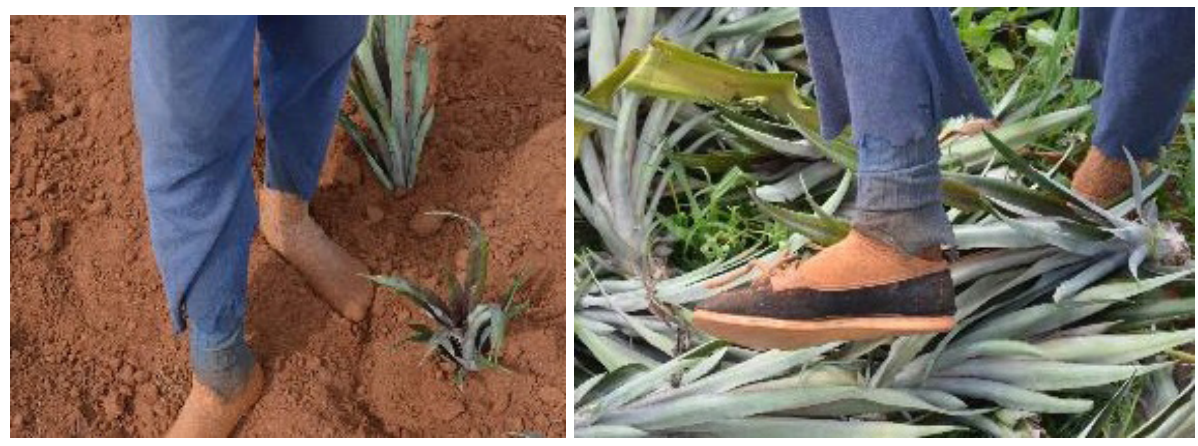

Fonte: autor

Os trabalhadores emitiram suas opiniões de como gostariam que fosse a proteção dos pés de forma convencional e contra quais fatores de risco, conforme os relatos a seguir: "...Gostaria de um modelo de bota de segurança bem leve e que fosse até o joelho; porém com elástico para não entrar terra..." (TR 09); “...Gostaria de uma sapatilha bem fina que não entre umidade..." (TR 10); “...Um calçado de cano longo com elástico para não entrar terra, porém que fosse leve e não esquentasse; protegendo os pés do calor do solo..." (TR 13); "...Gostaria de calçar uma sapatilha leve e fresca..." (TR 15); "...Gostaria de uma sapatilha de couro com cano longo e trava para não entrar terra..." (TR 16) ; "...Gostaria de usar uma bota de couro fino, cano curto e leve..." (TR 17); "...Seria adequado para o plantio da muda do abacaxi uma botina de couro fino, leve, fresco e que não entrasse terra..." (TR 18). 


\subsection{Tabela de Desdobramento da Qualidade e Matriz de Qualidade para Proteção dos Pés no Plantio das Mudas do Abacaxi}

A Tabela 01 corresponde à tabela de desdobramento da qualidade exigida para o produto (EPI) de proteção dos pés dos trabalhadores durante o plantio de mudas do abacaxi; a Figura 17 corresponde à matriz de qualidade destinada a fundamentar o projeto do EPI correspondente. Enquanto que na tabela os fatores ligados à qualidade (voz do usuário) e as especificações técnicas do produto (voz do especialista) estão apenas justapostos, na matriz de qualidade eles estão confrontados, com os pesos relativos relacionados à ponderação e à arbitragem. Por exemplo, os números 1, 3 e 9 da matriz indicam a intensidade de correlação (1 - baixa; 3 - média; 9 - alta) entre a qualidade exigida e a característica técnica do EPI.

Tabela 01: Desdobramento das Características Técnicas da Qualidade em função das Qualidades Exigidas do Produto para Proteção dos Pés no Plantio das Mudas do Abacaxi

\begin{tabular}{|c|c|c|c|c|}
\hline \multicolumn{2}{|c|}{$\begin{array}{l}\text { Qualidade Exigida (voz do } \\
\text { trabalhador) }\end{array}$} & \multirow{2}{*}{$\begin{array}{l}\text { Elementos da } \\
\text { Qualidade }\end{array}$} & \multirow{2}{*}{\multicolumn{2}{|c|}{$\begin{array}{c}\text { Características Técnicas da Qualidade } \\
\text { do Produto }\end{array}$}} \\
\hline Nível 1 & Nivel 2 & & & \\
\hline \multirow{17}{*}{ Conforto } & \multirow{3}{*}{ Tamanho apropriado } & \multirow{3}{*}{ Dimensões } & \multicolumn{2}{|l|}{ Comprimento } \\
\hline & & & \multicolumn{2}{|c|}{ Largura } \\
\hline & & & \multicolumn{2}{|c|}{ Altura } \\
\hline & \multirow{2}{*}{$\begin{array}{l}\text { Não atrapalhar os } \\
\text { movimentos }\end{array}$} & Matéria prima & \multicolumn{2}{|c|}{ Maleabilidade } \\
\hline & & Dimensão & \multicolumn{2}{|c|}{ Espessura } \\
\hline & \multirow{2}{*}{ Não machucar } & Matéria prima & \multicolumn{2}{|l|}{ Textura } \\
\hline & & Dimensão & \multicolumn{2}{|c|}{ Espessura } \\
\hline & \multirow{3}{*}{ Não esquentar } & Matéria prima & \multicolumn{2}{|c|}{ Resistência Térmica } \\
\hline & & Dimensão & \multicolumn{2}{|c|}{ Espessura } \\
\hline & & Cor & \multicolumn{2}{|l|}{ Tonalidade } \\
\hline & \multirow{2}{*}{$\begin{array}{l}\text { Facilitar a } \\
\text { transpiração }\end{array}$} & & \multicolumn{2}{|l|}{ Porosidade } \\
\hline & & Materia prima & \multicolumn{2}{|l|}{ Vazada } \\
\hline & \multirow{2}{*}{ Leveza } & Matéria prima & \multicolumn{2}{|l|}{ Densidade } \\
\hline & & Dimensão & \multicolumn{2}{|l|}{ Espessura } \\
\hline & \multirow{3}{*}{$\begin{array}{l}\text { Antialérgica / Não } \\
\text { coçar }\end{array}$} & & Textura & \\
\hline & & Matéria prima & Composiçãc & Tratamentos \\
\hline & & & $\mathrm{PH}$ & \\
\hline & Escoriação por folhas & Matéria prima & Fibrosidade & \\
\hline & serrilhadas & Dimensão & Espessura & \\
\hline & Perfuração por & Matéria prima & Fibrosidade & \\
\hline Protecão & espinhos & Dimensão & Espessura & \\
\hline Proteça0 & Picada por animais & Matéria prima & Fibrosidade & \\
\hline & peçonhentos & Dimensão & Espessura & \\
\hline & Impermeável a fluídos & & Porosidade & \\
\hline & e poeiras & IVaterı prima & Vazada & \\
\hline & & Modelo/Forma & Cano curto & \\
\hline & & 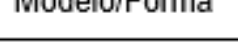 & Cano longo & \\
\hline & Bota & & Quantidade & Fixa \\
\hline & Bota & & Quantiadae & Móvel \\
\hline & & Forração & & Textura \\
\hline & & & $\begin{array}{l}\text { Materıa } \\
\text { prima }\end{array}$ & Espessura \\
\hline Desian & & & & Composição/Tratamentos \\
\hline Design & & Modelo/Forma & Cano curto & \\
\hline & & Iviodero/rorma & Cano longo & \\
\hline & Sapatilha & & & Fixa \\
\hline & Sapatuila & & Quantidade & Móvel \\
\hline & & Forração & & Textura \\
\hline & & & $\begin{array}{l}\text { Materia } \\
\text { prima }\end{array}$ & Espessura \\
\hline & & & & Composicão/Tratamentos \\
\hline
\end{tabular}

Fonte: autor 
Figura 17: Matriz da Qualidade para projetar o produto Proteção dos Pés no Plantio das Mudas do Abacaxi

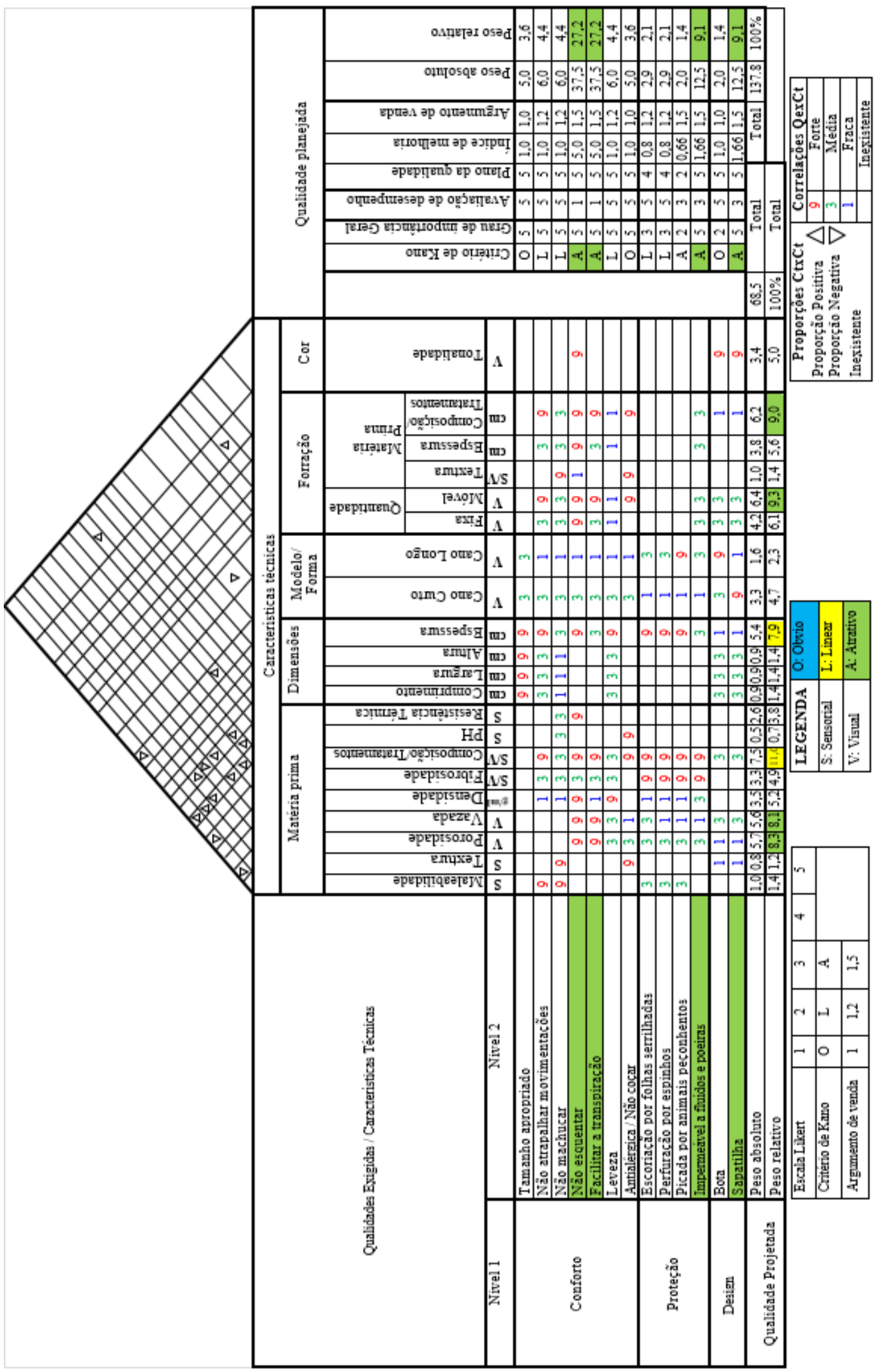

Fonte: autor 
Na matriz da qualidade para o desenvolvimento do produto proteção dos pés no plantio da muda do abacaxi, pode-se destacar na qualidade exigida pelos trabalhadores em relação ao conforto: não esquentar e facilitar a transpiração como qualidades atrativas. Nessa atividade foi identificada na AET uma necessidade quanto ao deslocamento de longas distâncias para buscar a muda do abacaxi, que podem chegar a ser de até $\mathbf{2 0 0}$ metros do local do plantio e várias vezes no decorrer da tarefa, como também milhares de repetições de abaixamento para enterrar a muda dentro das covas demarcadas pelo trator nos canteiros e posteriormente finalizando o fechamento com o auxílio dos pés. Este solo arado, de difícil locomoção, vai esquentando no decorrer do dia e, por isso, a necessidade de uma proteção para os pés com conforto térmico. Ressalte-se que, segundo resultado da escala de Borg, esta tarefa foi considerada intensa a extremamente intensa pela maioria dos trabalhadores.

Quanto ao requisito proteção, destaca-se a exigência de que o produto deve ser impermeável a fluídos e poeiras, pelo fato dos pés estarem diretamente em contato com o solo que acabou de ser gradeado, adubado e fertilizado. Durante a execução da tarefa de plantio, diferentemente das outras tarefas do cultivo do abacaxi, não existe a presença de ruas com folhas serrilhadas, espinhos ou presença de animais peçonhentos. Entretanto, nessa etapa há o contato com adubo sólido, fertilizante líquido e resquícios de animais incorporados ao solo, que podem provocar contaminações e/ou irritações a pele.

Chama a atenção que a sapatilha se destaca no design como qualidade exigida, pois ela é muito confortável, leve, adequada mesmo para grandes distâncias percorridas e não atrapalha os movimentos durante as inúmeras repetições. Além disso, protege os pés, especialmente devido às altas temperaturas e baixa umidade enfrentadas próximo ao meio dia, que podem chegar aos $42^{\circ} \mathrm{C}$ e fazem com que o solo alcance temperaturas de até $50^{\circ} \mathrm{C}$ na sua superfície, um dos principais fatores de risco nesta tarefa.

Para que as qualidades exigidas pelos trabalhadores no produto sejam atendidas, a equipe de projeto tem que priorizar as características técnicas da matéria prima como a porosidade, ser vazada, composição e tratamentos adequados, além da espessura que, quanto menor possível, proporcionará maior conforto na usabilidade do produto. Destaca-se também a necessidade de uma forração móvel para que o trabalhador possa fazer a regulação do conforto e proteção quanto ao solo quente, e possuir composição e tratamentos na matéria prima adequada otimizando assim as qualidades exigidas em destaque para o produto.

\subsection{Desenvolvimento do EPI para os pés no plantio da muda do abacaxi}

A interpretação dos resultados da Matriz da Qualidade proporcionou identificar os pesos relativos que se demonstraram com maior importância, tanto nos atributos como nas especificações técnicas, além de destacar os graus de importância dos requisitos segundo a percepção do usuário (requisito óbvio, linear e atrativo). Em decorrência da avaliação, foi possível desenvolver a tabela 02, da hierarquia de prioridades do produto proteção para os pés no plantio de mudas de abacaxi, identificando os requisitos óbvios, lineares e atrativos.

Os demais requisitos que constam na matriz da qualidade também influenciam 
no produto final, porém hierarquizar os que mais influenciam na qualidade exigida, auxilia na tomada de decisão da equipe de projeto caso necessitem priorizar ou até mesmo sacrificar um ou mais requisitos. No caso, não foram identificados requisitos óbvios.

Tabela 02: Hierarquia de Prioridades quanto ao Peso Relativo (PR) das Qualidades Exigidas e das Características Técnicas da Qualidade do Produto para Proteção dos Pés no Plantio

\begin{tabular}{|c|c|c|c|c|}
\hline \multicolumn{4}{|c|}{ Produto para proteção } & PR Plantio de Mudas \\
\hline \multirow{10}{*}{ Pés } & \multirow{4}{*}{$\begin{array}{l}\text { Qualidade ex- } \\
\text { igida }\end{array}$} & \multirow{2}{*}{ Conforto } & Não esquentar & 27,2 \\
\hline & & & Facilitar a transpiração & 27,2 \\
\hline & & Proteção & Impermeável a fluidos e poeiras & 9,1 \\
\hline & & Design & Sapatilha & 9,1 \\
\hline & \multirow{6}{*}{$\begin{array}{l}\text { Características } \\
\text { Técnicas }\end{array}$} & \multirow{3}{*}{ Matéria Prima } & Porosidade & 8,3 \\
\hline & & & Vazada & 8,1 \\
\hline & & & Composição/Tratamentos & 11,0 \\
\hline & & Dimensões & Espessura & 7,9 \\
\hline & & \multirow{2}{*}{ Forração } & Móvel & 9,3 \\
\hline & & & Composição/Tratamentos & 9,3 \\
\hline
\end{tabular}

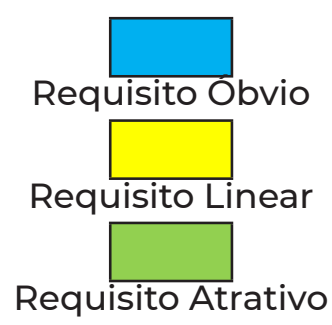

Fonte: autor

Através de uma busca na internet por produtos semelhantes à necessidade do design sugerido, identificaram-se as sapatilhas usadas em hidroginástica ou yoga. Este produto pode sofrer uma instrumentalização para adequação do produto final aos requisitos priorizados na atividade do plantio de mudas do cultivo do abacaxi, como foram identificadas a utilização de meiões de futebol e sapatilhas femininas como forma de proteção alternativa aos pés. Também podem ser feitas propostas de alteração na concepção do produto com adaptações de dispositivo(s)/acessório(s) como forma de regulagens para atender as variações em uma ou mais situações e/ou atividades, como a utilização das galochas e/ou polainas desenvolvidas para os motoqueiros. A forração móvel poderá ser uma meia com material adequado as especificações exigidas, onde o fabricante especifica que o produto possui material com sistema de ação hidrofílica de camadas ultra dry, que transfere rapidamente todo o suor e umidade para a camada externa da malha.

Essa associação de requisitos entre diversos produtos comercializados acaba dando muito mais opções de formas de proteção para dos pés ao trabalhador rural. Isso desde que a equipe de projeto possua compreensão da atividade exercida e conheça 
os requisitos dos produtos, para que dessa maneira possam selecionar produtos ou artefatos com potencial a serem associados, como também proporem alterações na sua concepção e formas de utilização com menor probabilidade de insatisfação de uso pelos trabalhadores do cultivo do abacaxi.

Desta maneira, através do conceito da gênese instrumental, já identificados anteriormente no próprio cultivo do abacaxi como demonstrado nas AET das atividades, sugere-se a concepção de um protótipo através da associação de produtos com potenciais características de proteção já existentes no mercado e utilizadas para outras finalidades em diversos setores, conforme pode ser observado na figura 18. É necessário ressaltar que a equipe de projeto também possui expertise para propor alterações tanto de instrumentalização como instrumentação nesses protótipos.

Figura 18: Esboço Digital/Virtual da Prototipagem Digital do Produto Proteção dos Pés para os Trabalhadores no Plantio do Cultivo do Abacaxi
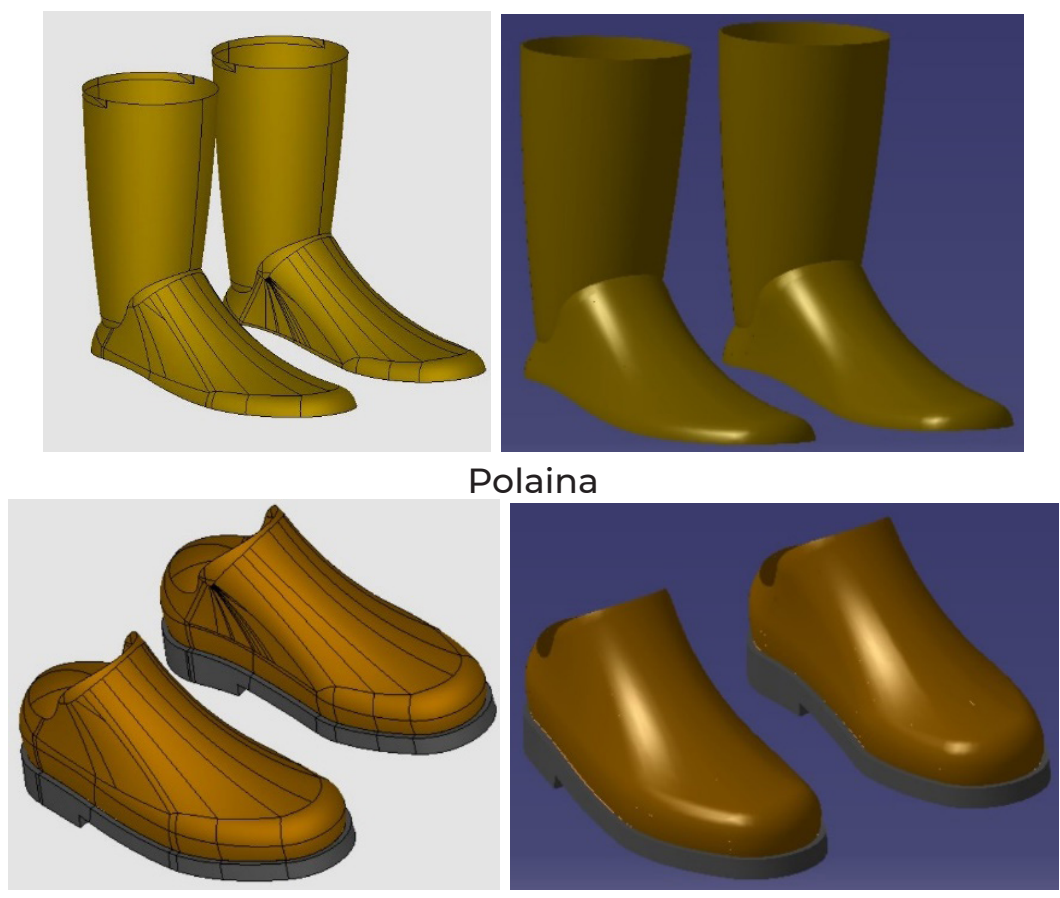

Galocha

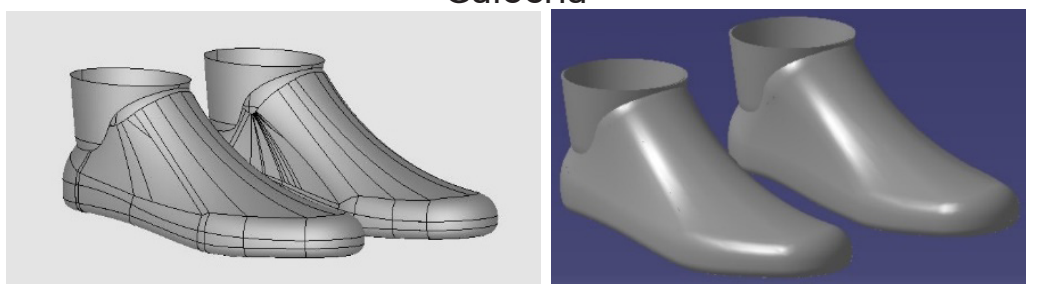

Sapatilha

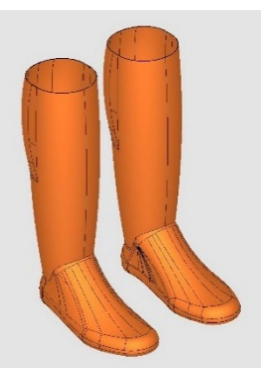

Forração Móvel Segunda Pele

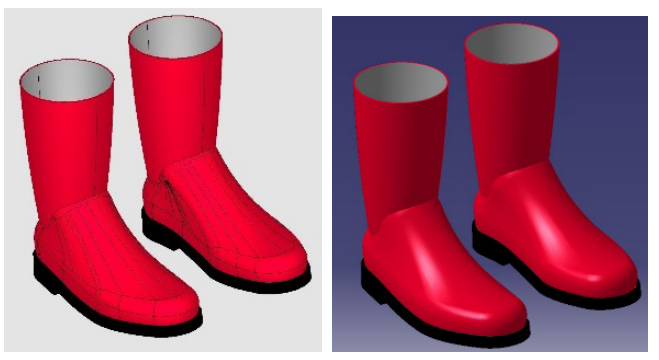

Galocha com Polaina Acoplada Fonte: autor 


\section{Conclusão}

Para proteção do trabalhador rural devem ser implementadas medidas de prevenção, proteção e controle dos fatores de risco. Porém o uso dos EPI, que deveria ser a última alternativa de proteção, acaba sendo a primeira. Os EPI utilizados na agricultura muitas vezes se revelam inadequados e desconfortáveis, gerando dificuldades operacionais e muita rejeição dos trabalhadores quanto a sua utilização.

Devem ser selecionados EPI que sejam simultaneamente adequados tecnicamente quanto ao risco da atividade exercida e confortáveis segundo avaliação do trabalhador usuário. Entretanto, isso raramente ocorre nas atividades agrícolas. Vale lembrar que, via de regra, os EPI são desenvolvidos para setores industriais diversos, onde dificilmente a atividade ou condições ambientais se assemelham à realidade ou às necessidades da agricultura. Consequentemente, os EPI utilizados na agricultura podem ser considerados ineficientes quanto a sua funcionalidade.

É fundamental que se desenvolvam projetos específicos de EPI para a agricultura, considerando a sua funcionalidade baseada em critérios ergonômicos, tanto para prevenir riscos de acidentes, como para oferecer conforto no uso. Igualmente importante é considerar a estética do design em sua concepção, o que ajudaria a minimizar a aversão do uso pelos trabalhadores rurais.

Como foi possível verificar neste trabalho, a Análise Ergonômica do Trabalho (AET) e o Desdobramento da Função Qualidade (QFD) para o desenvolvimento de novos produtos foram métodos que muito bem se complementaram para compreensão do trabalho, utilizando-se da tradução da "voz do cliente/trabalhador", suas necessidades e desejos.

As entrevistas realizadas, somadas às observações, filmagens e acompanhamento das atividades desenvolvidas pelos trabalhadores serviram para corroborar e complementar a AET. Os EPI utilizados se revelaram inadequados, tanto para a proteção como para o uso, além de serem considerados, de uma maneira geral, bastante desconfortáveis. Mais grave é que raramente são disponibilizados pelos contratantes, levando os trabalhadores ao improviso para sua proteção. Se por um lado, esta situação se revela muito complicada quanto à segurança, por outro lado mostra como a criatividade dos trabalhadores (identificada como "gêneses instrumentais") pode contribuir para o reprojeto e quanto a estética de equipamentos mais adequados e confortáveis para o desenvolvimento das atividades laborais.

A "Tabela de Desdobramento" do produto permitiu alcançar os requisitos esperados pelos clientes de acordo com as qualidades exigidas, que estabeleceram as características da qualidade do produto. A mensuração de dados gerados a partir da AET, através desta ferramenta, proporcionou um maior entendimento das necessidades e desejos dos trabalhadores pela equipe de projeto. Tornando-se assim factível a extração das principais características técnicas que interferem direta ou indiretamente na qualidade do produto desejado.

Com base na matriz "Casa da Qualidade" foi possível criar uma hierarquia de prioridades quanto às qualidades exigidas e as características técnicas da qualidade do produto proteção para os pés no plantio de mudas de abacaxi. Desta forma, foram contemplados requisitos do produto quanto: 
- Ao conforto: não esquentar e facilitar a transpiração;

- A proteção: ser impermeável a fluídos e poeiras;

- O design: ter o formato de sapatilha;

- A matéria prima: ter porosidade, ser vazada e composição/tratamentos adequados;

- As dimensões: espessura que não limite movimentos;

- A forração: ser móvel e possuir composição/tratamentos adequados.

Através das observações e expertise da equipe de projeto se complementou os requisitos do produto quanto:

- Ao modelo e formas: adaptações de dispositivo(s)/acessório(s) como forma de regulagens para atender as variações de necessidades e exigências na execução da atividade;

- A sua cor: com tonalidades claras para não reter calor.

A associação de requisitos entre diversos produtos comercializados acaba oferecendo muito mais opções de formas de proteção integrada. A equipe de projeto deve possuir compreensão da atividade exercida e delinear os requisitos do produto, para que assim possam ser selecionados produtos ou artefatos com potencial a serem associados, como também intervirem nas alterações da sua concepção e incorporar formas de utilização com menor probabilidade de rejeição ao uso pelos trabalhadores do cultivo do abacaxi. Quanto maior o entendimento da equipe de projeto sobre os requisitos, maior a capacidade de intervenção na concepção de novos produtos para proteção no cultivo do abacaxi.

Ao final da pesquisa, pôde-se observar a promissora aplicabilidade da associação dos métodos AET e da ferramenta "Casa da Qualidade" do método QFD para o desenvolvimento de novos produtos. Foi possível identificar as necessidades e desejos dos trabalhadores no plantio das mudas de abacaxi, como também foram priorizadas as principais características técnicas da qualidade no desenvolvimento de novos produtos de proteção para os pés.

Ficou inequívoca a apropriação e compreensão de conhecimentos por parte de todos os participantes da equipe de projeto que participaram dessa pesquisa, assim como a abordagem dialógica entre projetistas e trabalhadores mediada pelo artefato e sua atividade, sendo legitimado esse benefício do QFD, apontado por diversos autores.

Essa sistemática de desenvolvimento de produtos ergonômicos pode ser considerada como uma excelente opção na ergonomia de concepção para EPI de diversos setores e excepcionalmente os da agricultura, que é um setor constantemente postergado nas prioridades dos fabricantes. 


\section{AGRADECIMENTOS}

Os autores agradecem aos trabalhadores envolvidos na pesquisa e aos proprietários dos cultivos do abacaxi.

À FAPESP, pelo "Auxílio à Pesquisa n 2015/12907-6, Fundação de Amparo à Pesquisa do Estado de São Paulo (FAPESP)".

À CAPES, pela concessão da bolsa de doutorado.

"O presente trabalho foi realizado com apoio da Coordenação de Aperfeiçoamento de Pessoal de Nível Superior - Brasil (CAPES) - Código de Financiamento 001".

\section{REFERÊNCIAS}

ADISSI, P. J.; ALMEIDA, C. V. B. Riscos na produção do abacaxi: o caso do baixo Paraíba/ PB. In: Encontro Nacional de Engenharia de Produção, XXII, 2002, Curitiba-PR, Anais eletrônicos... Disponível em: <www.abepro.org.br/biblioteca/enegep2002 tr43 1257.pdf>. Acesso em 28 de abril de 2015.

AKBAR-KHANZADEH, F.; BISESI, M. S.; RIVAS, R. D. Comfort of Personal Protective Equipment. Applied Ergnomics, 26(3): 195-198, 1995.

BAXTER, M. Projeto de produto: guia prático para o design de novos produtos. 2ed. São Paulo: Editora Blücher, 2000.

BÉGUIN, P. (2008). Argumentos para uma abordagem dialógica da inovação. Laboreal, 4(2): 72-82, 2008.

BÉGUIN, P. A concepção dos instrumentos como processo dialógico de aprendizagens mútuas, pp. 205-222. In: FALZON, P. Ergonomia construtiva. São Paulo: Editora Blücher, 2016.

BOURMAUD, G. Da análise dos usos à concepção dos artefatos: o desenvolvimento de instrumentos, pp. 223-240. In: FALZON, P. Ergonomia construtiva. São Paulo: Editora Blücher, 2016.

CHENG, L. C.; MELO FILHO, L. D. R. QFD - Desdobramento da função qualidade na gestão de desenvolvimento de produtos. 2ed. São Paulo: Edgard Blücher, 2010.

DARSES, F.; FALZON, P.; MUNDUTEGUY, C.. Paradigmas e modelos para análise cognitiva das atividades finalizadas, pp. 155-173. In: FALZON, P.. Ergonomia. São Paulo: Edgard Blücher, 2007.

FATHALLAH, F. Musculoskeletal disorders in labor - intensive agriculture. Applied Ergonomics, 41(1): 738-743, 2010.

FERREIRA-DE-SOUSA, F. N.; SANTANA, V. S. Mortalidade por acidentes de trabalho entre trabalhadores da agropecuária no Brasil, 2000-2010. Cadernos de Saúde Pública, vol.32, n.4, Rio de Janeiro, 2016. Disponível em: <http://dx.doi.org/ 10.1590/0102-311X00071914>. Acesso em: 30 de agosto de 2016. 
GARRIGOU, A.; BALDI, I.; DUBUC, P. Contributos da ergotoxicologia na avaliação da eficácia real dos EPI que devem proteger do risco fitossanitário: da análise da contaminação ao processo colectivo de alerta. Laboreal, 4(1): 92-103, 2008.

GONZAGA, M. C.; TENCARTE, A. P. R.; DONATELLI, S.; ADISSI, P. J.; SANTOS, E. I. Análise Coletiva do Trabalho Executado no Cultivo do Abacaxi no Município de Guaraçaí SP. São Paulo: FUNDACENTRO, 2014.

GONZAGA, M. C. Proteção dos trabalhadores durante o cultivo de abacaxi contra ataques de serpentes peçonhentas. 199p. Tese (Doutorado em Engenharia Agrícola) Faculdade de Engenharia Agrícola, Universidade Estadual de Campinas, Campinas, 2017.

GUÉRIN, F.; LAVILLE, A.; DANIELLOU, F.; DURAFFOURG, J.; KERGUELEN, A. Compreender - Trabalho para Transformá-lo: a prática da ergonomia. São Paulo: Blücher, 2001.

IAC - INSTITUTO AGRONÔMICO DE CAMPINAS. Abacaxi IAC Gomo-de-mel. Disponível em: <http://www.iac.sp.gov.br/cultivares/inicio/Folders\%5CAbacaxi\% 5CclACGomo-de-Mel.htm>. Acesso em: 30 de agosto de 2016.

IIDA, I. Ergonomia - projeto e produção. 2 ed. São Paulo: Editora Blücher, 2005.

LÖBACH, B. Desenho industrial. Bases para a configuração dos produtos industriais. 4ed. São Paulo. Editora Blücher, 2012.

MADUREIRA, O. M. Metodologia do projeto: planejamento, execução e gerenciamento. 2ed. São Paulo. Editora Edgard Blücher, 2010.

MEIRELLES, L. A.; VEIGA, M. M.; DUARTE, F. J. C. M. Efficiency of personal protective equipment used in agriculture. Work, 41(1): 14-18, 2012.

PAZMINO, A. V. Como se cria: 40 métodos para design de produtos. São Paulo: Editora Blücher, 2015.

ROZENFELD, H. QFD (Quality Function Deployment). Instituto de Gestão de desenvolvimento de Produto. (NUMA/USP), 2010. Disponível em: <http://www.portaldeconhecimentos.org.br/index.php/por/content/view/full/10294>. Acesso em: 26 de outubro de 2015.

VEIGA, M. M.; DUARTE, F. J. C. M.; MEIRELLES, L. A.; GARRIGOU, A.; BALDI, I. A contaminação por agrotóxicos e os equipamentos de Proteção Individual (EPIs). Rev. Bras. Saúde Ocup. 32(116): 57-68, 2007.

WISNER, A. Por dentro do trabalho: ergonomia: método e técnica. São Paulo: Editora FTD, 1987.

WISNER, A. Questões epistemológicas em ergonomia e em análise do trabalho. p.2956. In: DANIELLOU, F. (Coordenador). A ergonomia em busca de seus princípios: debates epistemológicos. São Paulo: Edgard Blücher, 2004.

ZHANG, F.; YANG, M.; LIU, W. Using integrated quality function deployment and theory of innovation problem solving approach for ergonomic product design. Computers \& Industrial Engineering, 76(1): 60-74, October 2014. 